Creative Commons User License: CC BY-NC-ND

Abstracted by: EBSCOhost, Electronic Journals Service (EJS),

Google Scholar, Journal Seek, Scientific Commons,

Food and Agricultural Organization (FAO), CABI and Scopus

http://eoi.citefactor.org/10.11226/v25i3
Journal of Agricultural Extension

Vol. 25 (3) July, 2021

ISSN(e): 24086851; ISSN(Print); 1119944X

http://journal.aesonnigeria.org

http://www.ajol.info/index.php/jae

Email: editorinchief@aesonnigeria.org

\title{
Choice of Information and Communication Technology Tools in Tomato Marketing Among Smallholder Farmers in Kirinyaga County, Kenya \\ https://dx.doi.org/10.4314/jae.v25i3.8
}

\section{Kevin Orangi Mauti}

Department of Agricultural Economics and Extension, University of Embu, Embu, Kenya Email: kmauti5@gmail.com, Phone: +254795549796

\section{Ndirangu, Samuel Njiri}

Department of Agricultural Economics and Extension, University of Embu, Embu, Kenya Email: ndirangu.samuel@embuni.ac.ke, Phone: +254723987104

\section{Mwangi, Samuel Chege}

Department of Agricultural Economics and Extension, University of Embu, Embu, Kenya Email: mwangisamue2006@yahoo.com (Posthumous)

\section{Abstract}

This study examined the factors influencing the choice of information and communication technology (ICT) tools used in tomato marketing by smallholder farmers in Kirinyaga County, Kenya. Households were selected through a combination of purposive, two-stage stratified and probability proportionate to size sampling techniques. The study employed Semistructured interview schedules to collect data from the sampled small-scale tomato farmers. Factors affecting the choice of ICT tools in tomato marketing were identified using multivariate model. The study revealed that age, income, level of education, farmers' experience, and farm size, tomato production, willingness to pay for ICT tools, tomato prices and knowledge on ICT are predictors of choice of ICT use. ICT should be given in such a way that all farmers can get information as per their need. Policy makers and agricultural extension agents should create awareness on the use and importance of ICT tools for farmers to accept and use available ICT tools.

Keywords: Information and communication technology for tomato marketing, small hoder tomato farmers

\section{Introduction}

Agriculture sector is the pillar of the economy, where it contributes about 15 percent to the national gross domestic product (GDP) and more importantly, a majority of the population dependent on agriculture for their livelihoods (Kenneth \& Onyedikachi, 2021). Agricultural development is vital in the improvement of food and nutrition security, living standard and increase general growth (Tura \& Hamo, 2018).

Tomatoes production serve as a source of employment either directly or indirectly by increasing job opportunities and income to small scale tomato farmers than other staple crops (Khatun \& Rahman, 2020). Despite these contributions, the commodity is constrained by poor marketing arrangements. There is a very big margin between the price received by farmers and those paid by consumers, indicating inefficient 
marketing system. Marketing plays a vital role in improving food security and living standards among smallholder farmers in developing countries where vegetable production is affected by inability of farmers to fully participate in the market (Montagnini \& Metzel, 2017). Due to the perishable nature of tomatoes, farmers face marketing problems such as low tomato prices and market information being manipulated by few actors caused by disconnect between producers and consumers (Nyamba et al., 2020). Use of ICT tools provide a solution to these problems (Shemfe, 2019)

The production and the marketing system of tomato consist of uncounted relationships and arrangements which are based on structure conduct-relationship image at every marketing level, that is, from the production to the consumption (Adams et al., 2020). Marketing network is being moulded to give opportunities to the use of ICT, which is crucial for fresh fruit and vegetables that are perishable and thus requires a ready market (Owusu et al., 2018). Information communication technologies (ICT) provide new ways of conversing and sharing knowledge and information among farmers (Aldosari et al., 2018).

The use of ICT has increased the access to information and knowledge even in remote areas (Bahrini \& Qaffas, 2019). Application of information and communication technologies (ICT) has a benefit of linking and providing market information to small scale tomato farmers (Binta et al., 2019).

The effect of socioeconomic factors on mobile phone use is emphasised in local contexts; different studies focus on generic factors (Lubua, 2017). Social factors influencing the choice of ICT tool used, some are cultural, while others are learned and adopted over time (Alnosiaan, 2019). The purchasing power of users is one of the socioeconomic factors considered to affect the decision to use mobile phones among low-income societies since some users may fail to purchase a service due to their weak purchasing power (Lubua, 2019). Age, gender and income has been reported to have had influence on the use of ICT tools by smallholder fish farmers in the Southern Highlands of Tanzania (Benard, 2019).

Mobile use demands are expressed through a situation where the adoption of the facilitating technology is necessary to receive a certain service (Roztocki et al., 2019). In agriculture, to use mobile money transactions and receive agricultural tips; subscription is mandatory (Batista \& Vicente, 2020)

\section{Methodology}

The study was conducted in Kirinyaga County which is located between latitudes 001' and 00 40' South and longitudes 370 and 380 East. The county borders Murang'a County to the West, Embu County to the East and South and Nyeri County to the North West and also boarders a small part of Machakos County. It covers an area of 1,478.1 square kilometers. Its five sub counties considered were; Kirinyaga Central, Kirinyaga West, Mwea West, Mwea East and Kirinyaga East. The sub-counties were purposively selected because of tomato production. The County has a tropical climate and an equatorial rainfall pattern. It experiences the long rain 
Creative Commons User License: CC BY-NC-ND

Abstracted by: EBSCOhost, Electronic Journals Service (EJS),

Google Scholar, Journal Seek, Scientific Commons,

Food and Agricultural Organization (FAO), CABI and Scopus
Journal of Agricultural Extension

Vol. 25 (3) July, 2021

ISSN(e): 24086851; ISSN(Print); 1119944X

http://journal.aesonnigeria.org

http://www.ajol.info/index.php/jae

Email: editorinchief@aesonnigeria.org

season (March to May) and short rain season (October to November). The County is also known for high production of rice. Other major crops grown in the County include; maize, beans, French beans and other horticultural crops (Momanyi et al., 2019).

The study targeted small-scale tomato farmers across the five sub-counties in the County. The sample size was determined following the method used by Sarstedt et al. (2018), which is applicable for heterogeneous population. The households were selected using a combination of purposive, two-stage stratified, and probability proportionate to size sampling techniques. In the first stage, five sub-counties were considered based on tomato production. Once the sub-counties have been considered, a two-stage stratified sampling technique was applied to select one ward and subsequently one village from each ward in every sub-county. Finally, households were randomly selected from each of the selected villages to form a sample size of 384 . The population of the village determined the number of households selected from each village.

\section{Empirical model}

The purpose of this study was to evaluate the effect of selected farm socioeconomic factors on the choice of three ICT tools: mobile phone, radio, and television. Multivariate model was used to evaluate the factors affecting the choice of ICT tools used in marketing of tomatoes in the study area. In this case, the dependent variables were ICT tools, and the independent variables were the selected socioeconomic factors such as age, education level, size of family, farming experience, basic ICT skills, and farm size of the farmers. Unlike the use of binary probit regression to evaluate the effects of selected factors on the choice of each individual ICT tool, Multivariate model simultaneously regresses a combination of the three correlated binary equations against a single vector of explanatory variables. Multivariate therefore allows for the correlation of error terms in the binary equations, leading to reduced statistical bias and inefficiency in the estimates (Okello et al., 2020). Empirically the Multivariate model can be expressed as:

$Y_{i}=\beta_{0}+\beta_{1} X_{1}+\beta_{2} X_{2}+\cdots+\beta_{n} X_{n}+\varepsilon_{i}---\cdots$

Where: $Y_{i}$ is the $i^{\text {th }}$ dependent variable $(i=1,2,3$ for radio, television, and mobile phone respectively); $\mathrm{X}_{1}, \mathrm{X}_{2} \ldots . \mathrm{X}_{\mathrm{n}}$ are the independent variables (selected socioeconomic factors); $\beta_{1} \beta_{2} \ldots \beta_{n}$ are regression coefficients; and $\varepsilon_{i}$ is error term.

\section{Multicollinearity test}

Multicollinearity is a condition in which two or more explanatory variables in a multiple regression model are related with each other, and likewise related with the response variable (Obite et al., 2020). It can be determined through the variance inflation factor (VIF) (Lavery et al., 2019). When no factors are correlated, the VIFs will all be 1. A VIF between 5 and 10 shows high correlation that may be problematic. When the VIF is above 10, it can be assumed that the regression coefficients are wrongly estimated due to multicollinearity which should be handled 
Creative Commons User License: CC BY-NC-ND

Abstracted by: EBSCOhost, Electronic Journals Service (EJS),

Google Scholar, Journal Seek, Scientific Commons,

Food and Agricultural Organization (FAO), CABI and Scopus

http://eoi.citefactor.org/10.11226/v25i3
Journal of Agricultural Extension

Vol. 25 (3) July, 2021

ISSN(e): 24086851; ISSN(Print); 1119944X

http://journal.aesonnigeria.org

http://www.ajol.info/index.php/jae

Email: editorinchief@aesonnigeria.org

accordingly. For this study, the VIF ranges from 1.12 to 3.81showing weak multicollinearity which allows subsequent model procedures.

\section{Results and Discussion}

\section{Social Characteristics}

Farming is the main source of livelihood where $10.2 \%$ of respondents engage in nonfarming activities. This indicates that farming is the most available form of employment in the study area.

Table I: Social characteristics of farmers

\begin{tabular}{ll}
\hline Variable & Percentage \\
\hline Major occupation & 89.8 \\
Farming & 10.2 \\
$\begin{array}{l}\text { Non-farming } \\
\text { Knowledge on ICT }\end{array}$ & 99.2 \\
$\begin{array}{l}\text { Yes } \\
\text { ICT improves tomato prices }\end{array}$ & 73.7 \\
$\begin{array}{l}\text { Yes } \\
\text { Willingness to pay for mobile } \\
\text { phone } \\
\begin{array}{l}\text { Yes } \\
\text { Willingness to pay for television }\end{array} \\
\begin{array}{l}\text { Yes } \\
\text { Willingness to pay for radio }\end{array} \\
\text { Yes }\end{array}$ \\
\end{tabular}

\section{Enterprise Characteristics of Respondents}

Table 2 gives the results of the analysis of the respondents' enterprise characteristics. Most respondents (81.5\%) are fully farmers while $18.5 \%$ are involved in both farming and off - farm activities. This is because farm produce can be sold to earn income and be used as food by family members. It is only $18.5 \%$ of the responded who are involved in the off- farm employment where $91.5 \%$ earn less than Kes. 10,000, and few (1.8\%) earn Kes. 30,000 and above. This necessitates the call for tomato farming that will fetch more.

The majority (97.9\%) of farmers sell their output to earn income while it is only few $(2.1 \%)$ who produce for family consumption. The majority of farmers $(99.2 \%)$ do not access credit facilities.

The majority of respondents (54\%) carry out their tomato farming in a land less than 2 acres followed by $40.5 \%$ who carry out their tomato farming in land between 2 and 
Creative Commons User License: CC BY-NC-ND

Abstracted by: EBSCOhost, Electronic Journals Service (EJS), Google Scholar, Journal Seek, Scientific Commons,

Food and Agricultural Organization (FAO), CABI and Scopus
Journal of Agricultural Extension

Vol. 25 (3) July, 2021

ISSN(e): 24086851; ISSN(Print); 1119944X

http://journal.aesonnigeria.org

http://www.ajol.info/index.php/jae

Email: editorinchief@aesonnigeria.org

4 acres. Very few farmers $(2.1 \%)$ carry out their tomato farming in lands that are more than 6 acres.

A great number of farmers $(56.5 \%)$ carry out tomato farming on land with a title deed, $26 \%$ without title deed and $17.4 \%$ operate on a rented land. The majority of the farmers (47.7\%) earn Ksh.10000-20000 per month from their farming followed by $24.5 \%$ who earn Ksh.21, $000-30,000$ per month while $25.5 \%$ of farmers earn less than Ksh.10, 000 per month.

Most (63.8\%) farmers sell their tomatoes in a market which take between 51 and 100 minutes' walk while $26 \%$ sell to market of 50 minutes' walk. Only $10.2 \%$ of farmers who sell to a market of 100 and above minutes' walk.

Table 2: Enterprise characteristics of respondents

\begin{tabular}{ll}
\hline Variable & Percentage \\
\hline Off-farm employment & \\
No & 81.5 \\
& \\
Farm Income & \\
Less than 10,000 & 25.5 \\
$10,001-20,000$ & 47.7 \\
$21,000-30,000$ & 24.5 \\
Above 31,000 & 2.3 \\
Tomato production (crates) & 46.9 \\
Less than 200 & 35.7 \\
200-400 & 17.4 \\
More than 400 & \\
Land ownership & 17.4 \\
Rented & 26 \\
Notitle deed & 56.5 \\
Farm deed size & \\
(acres) & \\
$<2$ & 54 \\
$2-<4$ & 40.5 \\
4-<6 & 3.2 \\
Above 6 & 2.1 \\
Market distance & \\
(Walking minutes) & \\
Less than 50 & \\
51-100 & 26.0 \\
More than 100 & 63.8 \\
\hline
\end{tabular}

\section{ICT Tools Used in Marketing Tomatoes}

In analysing the extent of using ICT tools in marketing of the tomatoes, descriptive statistics were used which include frequencies and percentages. The majority of tomato farmers, $(82.6 \%)$ in the study area use mobile phones to access market information, followed by $78.4 \%$ of farmers who use radios, while $70.1 \%$ of respondents in the study area use television. Television is the least ICT tool being used as compared to mobile phone and radio. This indicates that mobile phone is the most preferred ICT tool in tomato marketing among the farmers sampled. Mobile phone increase the way in which farmers get and exchange agricultural information 
Creative Commons User License: CC BY-NC-ND

Abstracted by: EBSCOhost, Electronic Journals Service (EJS),

Google Scholar, Journal Seek, Scientific Commons,

Food and Agricultural Organization (FAO), CABI and Scopus

http://eoi.citefactor.org/10.11226/v25i3
Journal of Agricultural Extension

Vol. 25 (3) July, 2021

ISSN(e): 24086851; ISSN(Print); 1119944X

http://journal.aesonnigeria.org

http://www.ajol.info/index.php/iae

Email: editorinchief@aesonnigeria.org

(Khan et al., 2019). Table III gives the results of the descriptive statistics for the selected ICT tools.

Table 3: Extent of use of selected ICT tools

\begin{tabular}{ll}
\hline ICT tool & Percentages \\
\hline Radio & 78.4 \\
Television & 70.1 \\
Mobile phone & 82.6 \\
\hline
\end{tabular}

\section{Effect of selected socioeconomic factors on choice of ICT tools}

Socioeconomic factors affecting the choice of ICT tools used in marketing of tomatoes among smallholder farmers were analysed using multivariate model. The factors include age, level of education, experience, household size, off farm employment, farm size, knowledge on ICT tools, willingness to pay for ICT tools, farm income and tomato production. The multivariate regression results show that willingness to pay for a particular ICT tool was the most dominant in affecting the choice of that ICT tool. Willingness to pay for radio was significant for all the ICT tools at $1 \%$ level of significance. It however had a positive relationship with radio only and negative relationship for both Television and phone. This meant that those who were willing to pay for radio were more likely to use radio and less likely to use both television and phone. Similarly, willingness to pay for television was positively significant for television while negatively significant for both radio and mobile at $1 \%$ level of significance. This meant that those who are willing to pay for television are more likely to use television and less likely to use both radio and mobile phones. In addition, willingness to pay for mobile phone was significant for all the ICT tools at $1 \%$ level of significance. However, it was only positively determining use of mobile phone while negatively determining the likelihood of using both radio and television. This simply means that those farmers willing to pay for phone are more likely to use phone only ignoring both television and radio. These results mean that farmers are only willing to pay for one ICT tool at a time. A study by Palloni et al. (2018) indicated that more farmers are willing to-pay for Vodafone Farmers' Club service at low prices and less at high prices.

The effect of education level on the likelihood of using television and mobile phone was positive and significant at $5 \%$ level of significance. This shows that a unit increase in education level correlates with $6.8 \%$ increase in the likelihood of television use and $4 \%$ increase in likelihood of mobile use. This implies that respondents with better education are more likely to use mobile phone and television to acquire relevant information that could promote agricultural activities. These findings are consistent with those of Kafura et al. (2016); Yu et al. (2017) and Kumar et al. (2017) who indicated that education is a major factor in adoption and absorption of technology. However, education level negatively predicted use of radio. Udimal et al. (2017) found that small-scale farmers who have gone through formal education are likely to accept and use new technologies for agricultural development. This meant that less educated farmers are more likely to use radio to access market information. Specifically, a unit reduction in education level leads to 
Creative Commons User License: CC BY-NC-ND

Abstracted by: EBSCOhost, Electronic Journals Service (EJS),

Google Scholar, Journal Seek, Scientific Commons,

Food and Agricultural Organization (FAO), CABI and Scopus
Journal of Agricultural Extension

Vol. 25 (3) July, 2021

ISSN(e): 24086851; ISSN(Print); 1119944X

http://journal.aesonnigeria.org

http://www.ajol.info/index.php/jae

Email: editorinchief@aesonnigeria.org

$3.8 \%$ increase in the likelihood of radio use. Some radio programs are aired in local languages which are easily understood by non-educated farmers.

Age was also a significant determinant in the use of radio at $5 \%$ level of significance. The results show that an increase in age increases use of radio in accessing tomato market information. Precisely, a unit increase in age corresponds to $0.5 \%$ increase in the likelihood of radio use. A study by Krause (2020) indicated that radio use was well incorporated among older adult participants' daily lives.

Experience positively predicted use of radio tool at $5 \%$ level of significance. This implies that increase in experiences increases use of radio ICT tool. A unit increase in age relates to $0.7 \%$ unit increase in use of radio. This is contrary to findings by Emeana et al. (2020) who found that farming experience impart to farmer some negotiation skills thus, farmers make more calls when carrying out farming business. This study however, considered only mobile phone leaving out other forms of ICT tools. Yeh (2020) also reported that consumers who have used a certain technology for a long period will develop a cognitive lock.

Farm size was a significant predictor in the use of both radio and mobile phone tools. The variable was however positively significant for mobile but negatively significant for radio. A study by Boon \& Edler (2018) indicated that the more the land planted in a season, the more the inputs used and the more the expected output, thus making farmers to adopt and intensify the use of ICT tools for guaranteeing input and output markets. This meant that increase in farm size leads to increased likelihood of using phones while a decrease in farm size corresponds to increased likelihood of using radio. However, Kalema (2017) reported that farmers with large farm size do need ICT tools since they have already their target market compared to farmers with small farms. Further, market distance was a significant and positive determinant in the use of mobile phone at $5 \%$ level of significance. This meant that a unit increase in distance correlates with increased likelihood of using phone to acquire tomato market information. Similarly, knowledge on ICT has a significant positive relationship with the use mobile phone in obtaining market information at $5 \%$ level of significance. This implies that those who have the knowledge on ICT tools are more likely to use mobile phones in gathering market information. These findings are like the result of Verhoeven et al. (2020) who found that more use and exposure to ICT tools should be considered as a factor for someone to think positively towards ICT. A study by Hanemann \& Scarpino (2016) also considered focused on the importance of attending ICT courses and seminars that can increase ICT interests and skills among people. Use of mobile phones could improve the economic opportunities among farmers and traders by allowing them to access consumers (Minkoua Nzie et al., 2018). Interestingly, the perception that ICT improved tomato prices was positively significant across all ICT tools at $1 \%$ level of significance. This showed that those who believe ICT tools improve tomato prices are more likely to use all the ICT tools. Similar finding was reported by Quandt et al. (2020) that mobile phone use has increased farmers' income, price and productivity since farmers must communicate directly with brokers and consumers. 
Creative Commons User License: CC BY-NC-ND

Abstracted by: EBSCOhost, Electronic Journals Service (EJS), Google Scholar, Journal Seek, Scientific Commons,

Food and Agricultural Organization (FAO), CABI and Scopus
Journal of Agricultural Extension

Vol. 25 (3) July, 2021

ISSN(e): 24086851; ISSN(Print); 1119944X

http://journal.aesonnigeria.org

http://www.ajol.info/index.php/jae

Email: editorinchief@aesonnigeria.org

Additionally, farm income significantly explained the use of radio and television at $5 \%$ level of significance. The coefficient was positive implying that a unit increase in income corresponds with $7.2 \%$ increase in the probability of using a radio. These results agree with those by Eskia (2019); Li et al. (2020) that increased farm income impacted on farmer's decision to use ICT tools. The farmers with higher levels of income can afford to own the ICT tools and be able to cover all cost of operations in accessing market information than those with low-income levels. Lastly, tomato production was a significant predictor of both radio and television use at $5 \%$ level of significance. The variable was however negatively predicting use of both radio and television. This meant that a unit decrease in tomato production corresponds to decreased likelihood of using radio and television in marketing of tomatoes. The results are as shown in Table IV.

Table 4: Choice of ICT tools used in marketing of tomatoes

\begin{tabular}{|c|c|c|c|c|}
\hline Variables & Radio & Tv & Phone & VIF \\
\hline & $\beta(S . E)$ & $\beta($ S.E $)$ & $\beta($ S.E) & \\
\hline Constant & $-0.044(0.257)$ & $-0.380(0.262)$ & $-0.010(0.187)$ & \\
\hline Gender & $-0.002(0.032)$ & $-0.001(0.033)$ & $0.024(0.024)$ & 1.25 \\
\hline Age & $0.005(0.002)^{\star \star}$ & $0.002(0.003)$ & $-0.003(0.002)$ & 3.81 \\
\hline Education level & $-0.038(0.021)^{\star}$ & $0.068(0.022)^{\star \star}$ & $0.040(0.016)^{\star \star}$ & 1.46 \\
\hline Experience & $0.007(0.003)^{\star \star}$ & $\begin{array}{c}-8.17 e- \\
06(0.004)\end{array}$ & $-0.003(0.002)$ & 2.98 \\
\hline Household size & $0.009(0.012)$ & $-0.003(0.112)$ & $0.005(0.009)$ & 2.89 \\
\hline $\begin{array}{l}\text { Farming major } \\
\text { occupation }\end{array}$ & $-0.026(0.049)$ & $0.087(0.050)^{\star}$ & $0.018(0.035)$ & 1.98 \\
\hline Off farm employment & $-0.032(0.041)$ & $0.005(0.042)$ & $-0.050(0.040)^{\star}$ & 2.27 \\
\hline Farming credit & $0.102(0.127)$ & $-0.039(0.130)$ & $-0.099(0.093)$ & 1.12 \\
\hline Farm size & $-0.033(0.013)^{\star \star}$ & $0.007(0.013)$ & $0.026(0.009)^{\star \star}$ & 2.15 \\
\hline Land ownership & $-0.11(0.017)$ & $-0.006(0.017)$ & $-0.002(0.013)$ & 1.55 \\
\hline Labor & $-0.002(0.14)$ & $-0.026(0.015)^{\star}$ & $-0.018(0.011)^{\star}$ & 1.42 \\
\hline Market distance & $0.0001(0.0004)$ & $0.0001(0.0004)$ & $0.0008(0.0003)^{\star \star}$ & 1.33 \\
\hline Knowledge on ICT & $-0.129(0.132)$ & $0.201(0.135)$ & $0.307(0.097)^{\star \star}$ & 1.22 \\
\hline Willing to pay radio & $0.582(0.032)^{\star \star \star}$ & $-0.223(0.033)^{\star \star \star}$ & $-0.236\left((0.023)^{\star \star}\right.$ & 2.01 \\
\hline Willing to pay Tv & $0.109(0.027)^{\star \star \star}$ & $0.801(0.027)^{\star \star \star}$ & $-0.150(0.019)^{\star \star \star}$ & 1.53 \\
\hline Willing to pay phone & $0.118(0.035)^{\star \star \star}$ & $-0.248(0.036)^{\star \star \star}$ & $0.634(0.026)^{\star \star \star}$ & 2.02 \\
\hline $\begin{array}{l}\text { ICT improve tomato } \\
\text { prices }\end{array}$ & $0.261(0.039)^{\star \star \star}$ & $0.232(0.040)^{\star \star \star}$ & $0.411(0.028)^{\star \star \star}$ & 2.64 \\
\hline Farm income (log) & $0.072(0.028)^{\star *}$ & $0.054(0.028)^{*}$ & $-0.011(0.020)$ & 2.69 \\
\hline $\begin{array}{l}\text { Tomato production } \\
\text { (log) }\end{array}$ & $-0.045(0.015)^{\star *}$ & $-0.044(0.015)^{\star *}$ & $0.004(0.011)$ & 1.95 \\
\hline $\mathrm{R}$ squared & 0.76 & 0.80 & 0.85 & \\
\hline $\mathrm{F}$ & 56.73 & 71.11 & 102.78 & \\
\hline $\mathrm{P}$ & 0.000 & 0.000 & 0.000 & \\
\hline
\end{tabular}


Creative Commons User License: CC BY-NC-ND

Abstracted by: EBSCOhost, Electronic Journals Service (EJS),

Google Scholar, Journal Seek, Scientific Commons,

Food and Agricultural Organization (FAO), CABI and Scopus
Journal of Agricultural Extension

Vol. 25 (3) July, 2021

ISSN(e): 24086851; ISSN(Print); 1119944X

http://journal.aesonnigeria.org

http://www.ajol.info/index.php/jae

Email: editorinchief@aesonnigeria.org

\section{Conclusions and Recommendations}

Age, farmers' experience, farm size, willingness to pay for ICT tools, farm income and tomato production has significant influence on the choice of ICT tools used. Age, level of education, farm size, income and farmers' experience are significantly related to farmer's choice of different ICT tools. Using ICT tools in agricultural development greatly relies on the accessibility of ICT tools and farmers' preference for a particular ICT tool. Mobile phone was found to be the most ICT tool used in the marketing of tomatoes in Kirinyaga. Farmers were willing to pay for other ICT tools. ICT tools improves tomato prices

Farmers in Kirinyaga should be trained on how to use ICT tools in marketing of tomatoes. Government should lower the cost of acquiring market information of tomatoes through ICT tools. In addition, institutional factors that support use of mobile phone and other ICT tools such as electricity should be provided. Awareness should be created through extensions over ICT tools.

\section{References}

Adams, F., Wongnaa, C. A., \& Coleman, E. (2020). Profitability and choice of marketing outlets: evidence from Ghana's tomato production. Journal of Agribusiness in Developing and Emerging Economies.

Aldosari, F., Al Shunaifi, M. S., Ullah, M. A., Muddassir, M., \& Noor, M. A. (2019). Farmers' perceptions regarding the use of information and communication technology (ICT) in Khyber Pakhtunkhwa, Northern Pakistan. Journal of the Saudi Society of Agricultural Sciences, 18(2), 211-217.

Alnosiaan, A. (2019). Socio-cultural factors influencing the use of ICT in intermediate schools in Saudi Arabia. https://ore.exeter.ac.uk/repository/handle/10871/37449

Bahrini, R., \& Qaffas, A. A. (2019). Impact of information and communication technology on economic growth: Evidence from developing countries. Economies, 7(1), 21.

Batista, C., \& Vicente, P. C. (2020). Improving access to savings through mobile money: Experimental evidence from African smallholder farmers. World Development, 129, 104905.

Benard, R. (2019). Using information and communication technologies to enhance information sharing for improved fish farming productivity in Tanzania (Doctoral dissertation, Sokoine University of Agriculture). http://www.suaire.suanet.ac.tz/handle/123456789/3107

Binta, N., Tonny, W., \& Palash, S. (2019). Use of ICT in decision making of agricultural marketing : Factors determining of $f$ armers ' involvement. 17(2), 226-231.

Boon, W., \& Edler, J. (2018). Demand, challenges, and innovation. Making sense of new trends in innovation policy. Science and Public Policy, 45(4), 435-447.

Emeana, E. M., Trenchard, L., \& Dehnen-Schmutz, K. (2020). The revolution of mobile phone-enabled services for agricultural development (m-Agri Services) in Africa: The challenges for sustainability. Sustainability, 12(2), 485. https://www.mdpi.com/2071- 
Creative Commons User License: CC BY-NC-ND

Abstracted by: EBSCOhost, Electronic Journals Service (EJS),

Google Scholar, Journal Seek, Scientific Commons,

Food and Agricultural Organization (FAO), CABI and Scopus

http://eoi.citefactor.org/10.11226/v25i3
Journal of Agricultural Extension

Vol. 25 (3) July, 2021

ISSN(e): 24086851; ISSN(Print); 1119944X

http://journal.aesonnigeria.org

http://www.ajol.info/index.php/jae

Email: editorinchief@aesonnigeria.org

$1050 / 12 / 2 / 485$

Eskia, S. A. M. W. E. L. (2019). Assessment of factors influencing the use of ICTs in accessing market information among smallholder rice farmers in Kilombero District, Tanzania (Doctoral dissertation, Sokoine University of Agriculture).

Hanemann, U., \& Scarpino, C. (2016). Harnessing the potential of ICTs: Literacy and numeracy programmes using radio, TV, mobile phones, tablets and computers. UNESCO Institute for Lifelong Learning. Feldbrunnenstrasse 58, 20148 Hamburg, Germany.

Kafura Rumman Akter, Safiul Islam Afrad M.D., Prodhan Foyez Ahmed and Bhattacharjee Chakraborty Dipanwita (2016). Use of ICT as extension tool by the farmers of gazipur district in Bangladesh. Indian Research Journal of Extension Education, 16 (2): 1-5

Kalema, E.P. (2017). 'Importance of information and communication technology in Rice production among small scale farmers in Morogoro region, Tanzania.' A Dissertation submitted in partial fulfilment of the requirements for the degree of Master of Science in agricultural economics of Sokoine University of agriculture. Morogoro, Tanzania.

Kenneth, G. E., \& Onyedikachi, I. P. (2021). Selected Economic Sector Contribution to Nigeria's Gross Domestic Product. Sch Bull, 7(3), 49-59.

Khan, N. A., Qijie, G., Ali, S., Shahbaz, B., \& Shah, A. A. (2019). Farmers' use of mobile phone for accessing agricultural information in Pakistan. Ciência Rural, 49.

Khatun, M., \& Rahman, M. S. (2020). Postharvest loss assessment of tomato in selected locations of Bangladesh. Bangladesh Journal of Agricultural Research, 45(1), 43-52.

Krause, A. E. (2020). The role and impact of radio listening practices in older adults' everyday lives. Frontiers in Psychology, 11.

Kumar, R., Hudda, R.S., Chahal, P. and Yadav, K., (2017). Availability of information and communication technologies (ICTs) tools usages by farmers in Haryana, Int. J. Pure App. Biosci. 5 (3):648-653.

Lavery, M. R., Acharya, P., Sivo, S. A., \& Xu, L. (2019). Number of predictors and multicollinearity: What are their effects on error and bias in regression?. Communications in Statistics-Simulation and Computation, 48(1), 27-38. https://doi.org/10.1080/03610918.2017.1371750

Li, H., Huang, D., Ma, Q., Qi, W., \& Li, H. (2020). Factors Influencing the Technology Adoption Behaviours of Litchi Farmers in China. Sustainability, 12(1), 271.

Lubua Dr, E. W. (2019). The Influence of Socioeconomic Factors to the Use of Mobile Phones in the Agricultural Sector of Tanzania. The African Journal of Information Systems, 11(4), 2.

Lubua, E. W. (2017). An analysis of the e-Agriculture research field between 2005 and 2015, The International Journal of Engineering and Science, 6, 3, 119-125.

Minkoua Nzie, J. R., Bidogeza, J. C., \& Azinwi Ngum, N. (2018). Mobile phone use, transaction costs, and price: Evidence from rural vegetable farmers in Cameroon. Journal of African Business, 19(3), 323-342.

Montagnini, F., \& Metzel, R. (2017). The contribution of agroforestry to sustainable 
Creative Commons User License: CC BY-NC-ND

Abstracted by: EBSCOhost, Electronic Journals Service (EJS), Google Scholar, Journal Seek, Scientific Commons,

Food and Agricultural Organization (FAO), CABI and Scopus
Journal of Agricultural Extension

Vol. 25 (3) July, 2021

ISSN(e): 24086851; ISSN(Print); 1119944X

http://journal.aesonnigeria.org

http://www.ajol.info/index.php/iae

Email: editorinchief@aesonnigeria.org

http://eoi.citefactor.org/10.11226/v25i3

development goal 2: end hunger, achieve food security and improved nutrition, and promote sustainable agriculture. In Integrating landscapes: Agroforestry for biodiversity conservation and food sovereignty (pp. 11-45). Springer, Cham.

Momanyi, V. N., N Keraka, M., A Abong'o, D., \& N Warutere, P. (2019). Types and classification of pesticides used on tomatoes grown in Mwea irrigation scheme, Kirinyaga County, Kenya. European Journal of Nutrition \& Food Safety, 83-97.

Nyamba, S. Y., Kalungwizi, V. J., Mlozi, M. R. S., Busindeli, I. M., Kilima, F. T. M., MsuyaBengesi, C. P., ... \& Kiranga, E. (2020). Tomato Value Chain Information System in Tanzania: Lessons from Kilolo District and Dodoma Municipality, Tanzania. International Journal of Agricultural Science, Research and Technology in Extension and Education Systems, 10(1), 9-15.

Obite, C. P., Olewuezi, N. P., Ugwuanyim, G. U., \& Bartholomew, D. C. (2020). Multicollinearity effect in regression analysis: A feed forward artificial neural network approach. Asian Journal of Probability and Statistics, 22-33. http://www.sdiarticle4.com/review-history/53589

Okello, D. O., Feleke, S., Gathungu, E., Owuor, G., \& Ayuya, O. I. (2020). Effect of ICT tools attributes in accessing technical, market and financial information among youth dairy agripreneurs in Tanzania. Cogent Food \& Agriculture, 6(1), 1817287.

Owusu, A. B., Yankson, P. W., \& Frimpong, S. (2018). Smallholder farmers' knowledge of mobile telephone use: Gender perspectives and implications for agricultural market development. Progress in Development Studies, 18(1), 36-51.

Palloni, G., Aker, J., Gilligan, D., Hidrobo, M., \& Ledlie, N. (2018). Paying for Digital Information: Assessing Farmers Willingness to Pay for a Digital Agriculture and Nutrition Service in Ghana.

Quandt, A., Salerno, J. D., Neff, J. C., Baird, T. D., Herrick, J. E., McCabe, J. T., ... \& Hartter, J. (2020). Mobile phone use is associated with higher smallholder agricultural productivity in Tanzania, East Africa. PloS one, 15(8), e0237337.

Roztocki, N., Soja, P., \& Weistroffer, H. R. (2019). The role of information and communication technologies in socioeconomic development: towards a multidimensional framework. https://doi.org/10.1080/02681102.2019.1596654

Sarstedt, M., Bengart, P., Shaltoni, A. M., \& Lehmann, S. (2018). The use of sampling methods in advertising research: A gap between theory and practice. International Journal of Advertising, 37(4), https://doi.org/10.1080/02650487.2017.1348329.

650-663.

Shemfe, O. A. (2019). Evaluation of Small-scale Farmers' use of Information Communication Technology for Farm Management in Mahikeng Local Municipality (Doctoral dissertation, North-West University (South Africa)).

Tura, E. G., \& Hamo, T. K. (2018). Determinants of Tomato Smallholder Farmers Market Outlet Choices in West Shewa, Ethiopia. Journal of Agricultural Economics and Rural Development, 4, 454-460.

Udimal, T. B., Jincai, Z., Mensah, O. S., \& Caesar, A. E. (2017). Factors influencing the agricultural technology adoption: The case of improved rice varieties (Nerica) in the 
Creative Commons User License: CC BY-NC-ND

Abstracted by: EBSCOhost, Electronic Journals Service (EJS),

Google Scholar, Journal Seek, Scientific Commons,

Food and Agricultural Organization (FAO), CABI and Scopus

http://eoi.citefactor.org/10.11226/v25i3
Journal of Agricultural Extension

Vol. 25 (3) July, 2021

ISSN(e): 24086851; ISSN(Print); 1119944X

http://journal.aesonnigeria.org

http://www.ajol.info/index.php/jae

Email: editorinchief@aesonnigeria.org

Northern Region, Ghana. Journal of Economics and Sustainable Development, 8(8), 137-148.

Verhoeven, J. C., Heerwegh, D., \& De Wit, K. (2020). Predicting ICT skills and ICT use of University students. Encyclopedia of Education and Information Technologies, 12861304.

Yeh, H. (2020). Factors in the ecosystem of mobile payment affecting its use: From the customers' perspective in Taiwan. Journal of theoretical and applied electronic commerce research, 15(1), 13-29.

Yu, T. K., Lin, M. L., \& Liao, Y. K. (2017). Understanding factors influencing information communication technology adoption behavior: The moderators of information literacy and digital skills. Computers in Human Behavior, 71, 196-208. 